\title{
Investigating the lower ambient temperature limit for pre-cooling to be beneficial for athletic performance
}

\author{
Iris Broekhuijzen*, Simon Hodder, Maarten Hupperets, George Havenith \\ From 15th International Conference on Environmental Ergonomics (ICEE XV) \\ Portsmouth, UK. 28 June - 3 July 2015
}

\begin{abstract}
Introduction
When exercising in the heat, performance is deteriorated. It has been shown that pre-cooling can counteract this deterioration in the heat [1], but it is unclear what the effects of pre-cooling on performance are in temperate environments. Thus, the current study was performed to see if there is any difference in performance with pre-cooling at $24{ }^{\circ} \mathrm{C}$ and $27^{\circ} \mathrm{C}$, and thus if there is a threshold in environmental temperature above which pre-cooling becomes beneficial to performance. We hypothesised pre-cooling to enhance performance at both environmental temperatures.
\end{abstract}

\section{Methods}

Nine healthy males (mean (SD) age 24.2 (7.2) years; $\mathrm{VO}_{2}$, $\left.\max 60.6(6.2) \mathrm{mL} \cdot \mathrm{kg}^{-1} \cdot \mathrm{min}^{-1}\right)$ participated in the study. Six participants performed 4 experimental trials: CON27 (control, $27^{\circ} \mathrm{C}$ ), COOL27 (pre-cooling, $27^{\circ} \mathrm{C}$ ), CON24 (control, $24{ }^{\circ} \mathrm{C}$ ) \& COOL24 (pre-cooling, $24{ }^{\circ} \mathrm{C}$ ). Three participants only performed CON27 \& COOL27. Pre-cooling was applied for 30 minutes and during the warm-up before a cycling time trial. Participants were cooled using a cooling vest and sleeves made of a combination of a mesh fabric and pockets filled with hydrophilic silica gel, which was soaked and frozen overnight. 30 minutes of baseline measurements in room temperature $\left(23.3(0.7){ }^{\circ} \mathrm{C}\right)$ were taken, followed by 39 minutes of pre-cooling in testing climate of which the last 9 minutes participants were warming up. Performance was measured using a time trial equivalent to cycling for one hour at $75 \% \mathrm{VO}_{2, \max }$. Mean skin temperature $\left(\mathrm{T}_{\text {skin }}\right)$ was measured throughout the trial using 8 iButtons [2] and

\footnotetext{
* Correspondence: I.Broekhuijzen@lboro.ac.uk
}

Environmental Ergonomics Research Centre, Loughborough University, LE11 3TU, UK

\section{Results}

Results show a significant performance improvement at $27^{\circ} \mathrm{C}(\mathrm{p}=0.036$ (one-tailed)), but no significant differences are seen at $24{ }^{\circ} \mathrm{C}(\mathrm{p}=0.325$ (one-tailed)). This was strengthened by the Hopkins approach [5], which showed a $97 \%$ or a very likely chance of an improvement in performance at $27{ }^{\circ} \mathrm{C}$ following pre-cooling. Pre-cooling lowered both $\mathrm{T}_{\text {skin }}(\mathrm{p}<0.005)$ and $\mathrm{T}_{\text {body }}$ ( $\mathrm{p}<0.05)$, but not $\mathrm{T}_{\text {core }}$. Sweat rate was significantly lowered following pre-cooling at $27{ }^{\circ} \mathrm{C}(0.67(0.11)$ vs. $0.61(0.13) ; \mathrm{p}<0.05)$, but not at $24{ }^{\circ} \mathrm{C}(\mathrm{p}=0.075)$. Furthermore, thermal sensation was lower (i.e. cooler) following pre-cooling (27: 1.6 (1.4) vs. -4.0 (1.41), 24: $-0.33(0.94)$ vs. $-4.33(1.25)$; $\mathrm{p}<0.05)$ and thermal discomfort was increased (27: $1.2(0.4)$ vs. $2.8(0.75), 24$ : $1.0(0.0)$ vs. $3.5(1.2) ; \mathrm{p}<0.05)$ following pre-cooling.

\section{Conclusion}

Our results indicate that pre-cooling improves performance in $27{ }^{\circ} \mathrm{C}$, but not in $24{ }^{\circ} \mathrm{C}$ and thus that the threshold in environmental temperature for pre-cooling using the tested cooling vest and sleeves to become beneficial for cycling time trial performance appears to be above $24{ }^{\circ} \mathrm{C}$. 


\section{References}

1. Faulkner SH, Hupperets M, Hodder SG, Havenith G: Conductive and evaporative precooling lowers mean skin temperature and improves time trial performance in the heat. Scand J Med Sci Sports 2015,

25:183-189, Jun.

2. $9886: 2004$ ISO: Ergonomics. Evaluation of thermal strain by physiological measurements.

3. Hardy JD, EF Du Bois, Soderstrom GF: Basal Metabolism, Radiation, Convection and Vaporization at Temperatures of 22 to $35^{\circ} \mathrm{C}$.: Six Figures. J Nutr 1938, 15(5):477-497.

4. Borg GA: Psychophysical bases of perceived exertion. Med Sci Sports Exerc 1982, 14(5):377-381.

5. Hopkins WG: A spreadsheet for deriving a confidence interval, mechanistic inference and clinical inference from a $\mathrm{p}$ value. Sportscience 2007, 11:16-20.

doi:10.1186/2046-7648-4-S1-A2

Cite this article as: Broekhuijzen et al:: Investigating the lower ambient temperature limit for pre-cooling to be beneficial for athletic performance. Extreme Physiology \& Medicine 2015 4(Suppl 1):A2.

\section{Submit your next manuscript to BioMed Central} and take full advantage of:

- Convenient online submission

- Thorough peer review

- No space constraints or color figure charges

- Immediate publication on acceptance

- Inclusion in PubMed, CAS, Scopus and Google Scholar

- Research which is freely available for redistribution

Submit your manuscript at www.biomedcentral.com/submit 